\title{
The Sound of My Voice: Self-Revelation Through Autoethnography
}

\author{
Louise Godwin \\ RMIT University, Australia
}

This essay represents my attempt to develop an expanded voice-as-researcher. My intent is to create a space for an improvisatory and playful process of self-discovery through writing aimed at extracting deeply-held, even concealed, possibilities rarely invoked in my practices as researcher. To facilitate this process of self-discovery, I use a binaryconstructed notion of my separate musician and researcher voices to experiment with placing three previously created text-based and musical works in dialogue. Reflecting on my bricoleur researcher tendencies, I tinker with methodology, lightly appropriating a post-representational approach to frame these works as co-researcher-provocateurs in this essay. Punctuating the essay with moments of autoethnographic writing, I weave these text-based and musical works together with two gestures - the cartographic system of Fernand Deligny's wander lines and the musical form of Charles Ives's String Quartet No.2-to explore the challenges of navigating identity, voice, and self-disclosure in scholarship. The essay concludes with a confession of anxiety as an illusionary deceit, and the final self-revelation of my voice. My sound.

Keywords: self-disclosure, self-revelation, autoethnography, identity, anxiety

Whoever is educated by anxiety is educated by possibility, and only he who is educated by possibility is educated according to his infinitude. Therefore possibility is the weightiest of all categories. (Kierkegaard [1844] 2014, 110)

I $\mathrm{n}$ this essay, I embrace the weight of possibility in my reflection on the problems and potentials around self-disclosure and the development of researcher voice in scholarship. I use the one-way mirror to metaphorise a research frame and conceive the identity project as socially-and individually-mediated process, and to playfully obfuscate the boundaries between different representations of voice. Inspired by Max van Manen's (2007) representation of phenomenology of practice, this process opens up "possibilities for creating formative relations between being and acting, self and other, interiorities and exteriorities,

(C) Louise Godwin. The content of this article is the sole responsibility of the author. The ACT Journal and the Mayday Group are not liable for any legal actions that may arise involving the article's content, including, but not limited to, copyright infringement. 
between who we are and how we act” (12). Following the work of Stuart Hall (1991), the essay can be read as an attempt to locate myself transparently at the intersection of two images of self: my own reflection, and that reflected in the gaze of the other. Put simply, my aim is to explore the intersectional space within the one-way mirror, using this essay to enter the space between self and other and reveal my identity and voice as researcher.

To achieve my aim, I create the pretence of a mediated dialogic encounter between three of my own works: two unpublished text-based essays and an audio recording: "On Becoming a Counsellor" (Godwin 2006), "Wander Lines as Visual Metaphor for Journeys in Life and Music" (Godwin 2017), and "Lou's Modal Menagerie" (Foot, Godwin, and Tunca 2017). These are co-created works in which the presence of other collaborators is acknowledged. The two, text-based works contain the thoughts and ideas of writers, theorists, and philosophers, all of whom attend through their published words. The audio recording, in contrast, captures the unique musical gestures and sounds of three musicians. As a combination of predetermined materials and improvised offerings, this work is co-created in the moment, with the presence of each collaborator shared and felt in the bodily-made and aurally-shared creation of vibrations or sound.

Using an autoethnographic gaze to "zoom backward and forward, inward and outward" (Ellis 2004, 37), I make transparent the thematic concerns of each work as a biographical device to disclose my own concerns. Adopting a post-representational approach, I frame these three works as co-researcher-provocateurs (Richardson and St Pierre 2008), and place them in dialogue, guided by Charles Ives's String Quartet No. 2, using each part as headings. Ives's work is composed in three parts-i. Discussions, ii. Arguments, and iii. The Call of the Mountains-with each offering a programmatic representation through music of dialogue between the four members of the quartet.

Before inviting the three works into the mediated dialogic encounter, I reconstruct the story of each separately. I do not aspire to any form of truth, objective or other, but instead construct a web cradling my retelling such as that called forth by Walter Benjamin (1969) in The Storyteller.

When the rhythm of work has seized him, he listens to the tales in such a way that the gift of retelling them comes to him all by itself. This then is the nature of the web in which the gift of storytelling is cradled. (91)

Godwin, Louise. 2019. The sound of my voice: Self-revelation through autoethnography. Action, Criticism, and Theory for Music Education 18 (2): 57-72. http://dx.doi.org/10.22176/act18.2.57 
This approach to retelling is a means of self-revelation: a tool or ploy to engage in written self-disclosure and reflection on development of voice-as-researcher. My approach is inspired by Karen V. Lee's (2007) essay, "Confessing Takes Courage," on her process of writing a confessional, and motivated by my drive toward selfrevelation as part of the larger project of developing a congruent voice representing all activities and parts of self. The three works are individual acts of self-disclosure, each representing discrete points in my life defined by time and practice. They are also anchored momentarily in this time and place through my current writing and research as a doctoral candidate and my music making as a cellist.

In preparation for placing the three works in dialogue, I engaged in a keyword analysis of the two written works to elucidate the concerns and emotions with which I was preoccupied at the time of writing each (2006 and 2017). Next, I listened to the audio recording, calling upon memories of concerns and emotions associated with the co-creative collaborative working process during the years of 2015 to 2017. Finally, I gathered together these concerns and emotions to create a series of preoccupations, or touchstones (see Figure 1), around which the subsequent dialogue between the three works is structured. This process allowed my existential epistemological stance to embrace the weight of possibility, the "terrible as well as the joyful" (Kierkegaard [1844] 2014, 110). Following Peter Gouzouasis and Karen Lee's (2002) and Gouzouasis's (2008) ${ }^{1}$ use of the musical form of a fugue to guide the writing of inquiry, I use Ives's String Quartet No. 2 as guide for structuring the exchange and interaction between works.

This essay sits alongside my doctoral research study investigating professional classical musicians' experiences in other-than-classical music, framed by the notion of third space (Bhabha 1994). My study incorporates a series of autoethnographic writings-including journal entries, conference papers and articles-to demonstrate that "autoethnography is both process and product" (Ellis, Adams, and Bochner 2011, 1). Collectively, this series of works exposes my standpoint as researcher-including my beliefs, biases and assumptions-and explores my own phenomenology of practice.

\section{Work 1-On becoming a counsellor}

"On Becoming a Counsellor" (2006) is a reflective assessment task submitted as a course study requirement and written toward the tail-end of a difficult period in 
my life. I had ventured into the space of existential psychotherapy, through regular sessions of dynamic psychotherapy, and was studying to become a counsellor.

I rediscovered this essay in 2017. On returning home from a week spent as a researcher observing a residential creative music program that involved improvising musicians, I was exploring the role of anxiety in fieldwork. I had done some preliminary reading of methodology literature and was mapping the early outline of a possible article on the topic.

Venturing into the space of anxiety is not difficult for me. I live with anxietyrarely crippling, sometimes debilitating, often impeding, and always present. As a consequence, I regularly audit aspects of my life as a means to both acknowledge my anxiety as a management strategy, and to control any excessive desire to cleave to my anxieties in ways that I have learned will be counter-productive, including my researcher tendencies toward confession through excessive self-disclosure, self-criticism, and self-scrutiny.

My process of auditing anxiety in this 2017 moment led me both toward the desire to compose an inquiry on anxiety in qualitative research, and the counterbalancing desire to examine my evidence supporting such a research endeavor. The data providing evidence of my anxiety during the fieldwork experience takes the form of diary notes and reflections recorded during fieldwork. These notes expand the memory of my body's response to anxiety: a migraine on day two, my neurotic internal response to a question about my use of the limited Internet, my sense of being unanchored following a complex conversation with a key informant, and the relief of a moment of unspoken recognition of my anxiety by another in an invitation to 'walk with me.' This evidence felt solid, unquestionable: it existed.

The next step in the auditing process required that I consider, "Why was my anxiety heightened during this field trip?” In pondering that question, I was reminded of a quote drawn from a biography of Sören Kierkegaard that I use as a tool with which to measure anxiety, and returned to the 2006 essay to find the precise quote.

Kierkegaard believed that people 'cleave' to their anxieties or wounds and confessed that he loved his own melancholy, truly loved it. While the cure for his melancholy was there, he would not let himself be cured of it, so identified was he with his sorrow that he could not imagine himself without it. So invested was he in the poetry of his sorrow that he would not give it up. ${ }^{2}$

I return to this quote surprisingly regularly in life. In moments of the melancholy that often accompanies anxiety, I use this quote as a means to assess the 
validity of my feelings. Asking questions of myself-Am I giving in to the poetry of my own sorrow? Am I succumbing to melancholy because I desire it more than the alternative?-I test my attachment to the feeling, and my motivation for grasping it, giving myself permission to let go.

\section{Work 2-Wander Lines as visual metaphor for journeys in life and music}

"Wander Lines as Visual Metaphor for Journeys in Life and Music" (2017) ("Wander Lines") is a rough draft of a possible book chapter arising from a paper, with the same title, presented at the Women in the Creative Arts Conference held at the Australian National University (August 2017). The reasons for my inability to complete this piece of writing are currently unclear. Perhaps the title contains the answer. As a portion of writing attached to my doctoral study, I am reluctant to give it permanence, to disclose my own wander line too soon. The concept of wander line has gained a hold of my research in a way I've not yet been able to fully justify. As a result, the wander line might more accurately be framed as a belief, or conviction, than a concept. So, what is a wander line?

Fernand Deligny (1913-1996), French experimental sociocultural educator and creative essayist, developed a series of anti-institutional, collectively-run, residential programs (called 'tentatives') for children and adolescents with autism and cognitive disabilities in the 1950s. These residential programs were established in opposition to the state-run psychiatric institutions of the day and were underpinned by a philosophy that rejected the positivist medical doctrines of the day, such as psychiatry and psychoanalysis (Milton 2016, Hilton 2015). In this way, Deligny's work and philosophy heralded the era of mid-twentieth century normalisation and the rejection of a view of disability as pathological deviations from the predominant norm. In contrast, he searched for "a mode of being that allowed [the individual] to exist even if that meant changing our own mode" (Deligny 2014, 79). Even today, Deligny's goal remains relevant in contemporary postmodern theoretical debates in the field of disability and education.

In the essay The Arachnean (2014), Deligny uses the metaphor of the spider's web to trace his exploration of "the network as a way of being," founded on "vague (as in 'the verb vaguer means to stray, to wander about at random') trajectories directed by innate drives" (37), as opposed to the "path of the thought-out project" 
(50). Deligny saw this as a new mode of social organisation and political ethos, and mapped the trajectories, gestures and movements of autistic children living within his tentative in Cévennes, France (see Images 1-3 below). As "cartographer of Wander Lines," Deligny and his colleagues developed a cartographic system for tracing the children's trajectories, sounds and gestures as they wandered their daily routes. The wander line drawings were works-in-progress, layered over time as part of an ongoing project (Milton 2016). The children's paths appear to be guided by other forces, such as underground waterways (Hilton 2015), suggesting some form of search for personal touchstones.
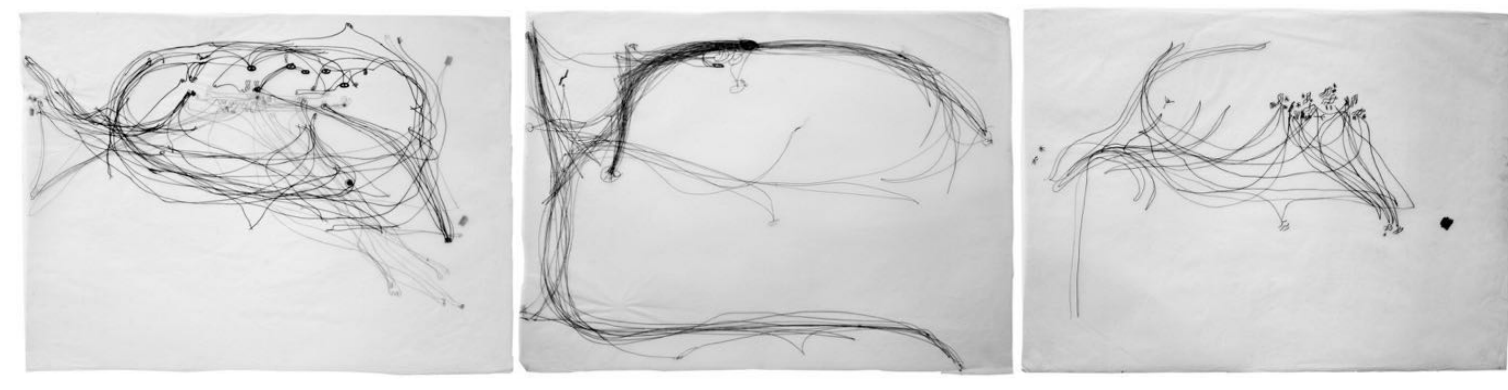

Images 1-3: Deligny, Wander line tracings; Image: Archives Jacques Allaire and Marie-Dominique Guibal; Reproduction: Anaïs Masson. Copyright: Univocal Publishing

For the purpose of my doctoral research, I adapt Deligny's wander line, shaping it to my own purpose. I do so with a sense of permission based on personal involvement with people with intellectual disabilities. My mother and aunt worked in disability, as physiotherapist and social worker respectively, and I worked for eight years with an advocacy organisation formed by, and for, parents and family members of individuals with intellectual disabilities living in shared supported accommodation. Resisting my current reluctance to look back, I call upon a myriad of memories, choosing two. First, my primary school aged siblings and myself at the residential home for 'retarded' children celebrating an early Christmas before staff would take their 'favourite' child home to share their own family lunch. We think of the unwanted children left behind, and pose unanswerable questions about absent birth families. Second, my primary school aged daughter sitting on the bench outside my office reading to a 50 year old man, his life spent within the boundaries of a large-scale institutional community. She recalls this formative moment, retold by me to remind us both of things we must not forget. 
So, while Deligny's visual images echo my own messy journey in music, more important are the values of social change, justice, and inclusion that underpin his ethos. In the same way that the words about Kierkegaard's own attachment to anxiety affirms the role of anxiety in my life, Deligny's notion of the wander line affirms the evolving discourse between innate physiological drives (instincts) and learned rational drives (intuitions).

\section{Work 3-Lou's Modal Menagerie}

\section{[Audio link]}

"Lou's Modal Menagerie" is an audio recording that brings together a set of modal tunes from Finland ("Katu" composed by Hannu Kella) and Sweden ("Tralalavalsen" composed by Ola Bäkström) with a tune of my own ("Something in $7 / 8$ "). I originally conceived the set of tunes, with the arrangement evolving in a collaboration between Jessica Foot (5-string fiddle) and myself (cello) during 2016 to 2017 as we developed repertoire for our duo Big Fiddle Little Fiddle. We invited Volga Tunca to contribute a darabuka improvisation for the audio recording captured in my kitchen by sound engineer/producer Mischa Herman as part of our project titled The Kitchen Recording. This project is the culmination of three years of collaboration between Jessica and myself that consisted, principally, of regular sessions exploring, jamming, arranging and writing music together in my kitchen, all the while, drinking tea from ever-replenishing teapots.

This recording is, in its own way, an aural representation of one possible version of my own wander line. The voice of the cello betrays my origins as a tertiary trained classical musician. The 'chop' sound ${ }^{3}$ of bow hair and rhythmic drive reflect my journey into folk music, in particular the decade spent in the world of Scottish fiddle music. The origins and influences of the first two tunes map my travels into folk music of Scandinavia, with my own tune offering a glimpse into a recent step into music of the Middle East. And dancing around and between my sound is that of my musical collaborators; Jessica and our friend Volga.

The Kitchen Recording was inspired by an intention that originates in the intimate experience of two people sitting with instruments to create musical sounds together. Like bowerbirds, Jessica and I select melodies and collect sounds. We talk, play and explore, learning to trust our individual quirks, idiosyncrasies, 
strengths and weaknesses. While never quite on the same path-for whoever iswe manage to negotiate the moments when the music asks us to walk 'in step.' Individual aesthetics and musical desires rub up against each other in abrasive moments of confrontation. Creative urges and energies, at times uncompromising, challenge the relationship while promising rewards.

Profound personal moments of this collaborative process are retained in my memory. In one moment, I struggle to find a way to accompany a melody Jessica has brought to me. It's a tune with an old-time feel, and I don't (won't?) play oldtime music. Our negotiation is a struggle. Her youthful desire to become, my middle-aged desire to be. The struggling symbiotic, mutually dependent, components of the lifelong identity project. This complex inter- and intra-relational dynamic is hard for me. It's challenging. This young woman is only ten years older than my eldest daughter. What am I doing playing music with her? What is she doing playing music with me? I can't do this. I can't be what she wants me to become. And I cry. We sit. And then I close my eyes, letting go of my attachment to the poetry of this existential moment, indeed terrible as well as joyful. In a profound awareness of my trust and commitment to this young woman and myself, I play.

My invitation of "Lou's Modal Menagerie" into this dialogic encounter with the two text-based works reveals the complex dance between trust, faith and vulnerability. The recording exposes the sound of bow hair on the wood of the stick, the squeals of a bow misplaced on a string, the precarious thrill of a decision to play too fast, the vulnerable disclosure of a note not placed precisely in tune. The recording lays bare human frailty, the limits of ability, and accepts the consequences. It is, at least for me, an existential confession. This is my voice, replete with anxiety and the challenges of harmonising instinct and intuition.

\section{Prelude to a dialogic encounter among three pieces}

In the same way that the young subjects of Deligny's cartographic systems reveal their personal touchstones on their paths through the landscape, the three works disclose a set of keywords, which I conceive as dialogue touchstones (see Figure 1 below). In the dialogic encounter, I imagine "On Becoming a Counsellor" as the dominant voice of idealistic hope in the conversation. "Wander Lines" stands at a mature distance, its voice torn between the need for scholarly authority, and a desire to communicate the complex profundity of life. This is not a surprising dynamic. "On Becoming a Counsellor" is highly personal, founded on self-disclosure, 
and never intended for publication. "Wander Lines," in contrast, uses personal information as data to test the application of the concept of wander lines to my own life and career for the purpose of potential publication. One seeks to confess, the other to understand. One aims to disclose fully, the other to disclose just enough.

"Lou's Modal Menagerie" (2017) is like the dinner party guest, invited with the best intent but with a foreboding sense that perhaps they ought not to have been. I am reminded of Margaret in E. M. Forster's Howard's End ([1910] 1997) and her naïve but well-intended decision to invite Mrs. Wilcox to her luncheon. Who is gaining benefit from the presence of this guest? How will their presence leave us all feeling? Will it be a complete failure, or will their presence transcend the conversation?

My contribution to "Lou's Modal Menagerie" is powerfully motivated by an urge to confess and disclose, and to find my voice within the one-way mirror. As I listen to the recording and experience my body's responses to both the sound and the memory of making this sound, I see myself reflected. When I imagine a listener, I draw upon my own memories of performing this music live for an audience, and I see myself heard by others. And this moment of self-revelation in the intersectional space encourages me to move, and live, onward.

\begin{tabular}{|c|c|c|}
\hline \multicolumn{3}{|l|}{ Dialogue Touchstone } \\
\hline $\begin{array}{l}\text { "Wander Lines as Visual } \\
\text { Metaphor for Journeys } \\
\text { in Life and Music" (2017) }\end{array}$ & $\begin{array}{l}\text { “On Becoming a } \\
\text { Counsellor" (2006) }\end{array}$ & $\begin{array}{l}\text { "Lou's Modal Me- } \\
\text { nagerie" (2017) }\end{array}$ \\
\hline Journey (=8) & Journey (=6) & Journey \\
\hline Voice $(=5)$ & Voice $(=6)$ & Voice \\
\hline \multirow[t]{4}{*}{ Existential $(=1)$} & Existential (=8) & Existential \\
\hline & Anxiety (=19) & Anxiety \\
\hline & Trust (=11) & Trust \\
\hline & Sorrow \& Joy $(=3)$ & Sorrow \& Joy \\
\hline
\end{tabular}

Figure 1: Dialogue touchstones (with frequency of keyword occurrence in text works represented numerically)

As I write, I listen to Ives's String Quartet No. 2 recorded by the Emerson String Quartet. The early moments of the first movement (Discussions) often play in my memory. I return to the sound of the musicians' bows as they waver on the strings: a profound telling of what is human in the playing of music. In the score of 
this three part composition, Ives writes (below the title) that the four members of the string quartet "converse, discuss, argue (in 'Politick'), fight, shake hands, shut up-then walk up the mountain side to view the firmament!" (Morrison n.d.). I follow those ideas as I write the dialogic encounter.

\section{Movement 1-Discussions (Andante moderato-Andante con spirito- Adagio molto) [Audio link]}

Having shared their individual stories, the three works note a shared preoccupation with journey and voice, and ponder the relationship between the two. "On Becoming a Counsellor" speaks quietly with a naïve faith in the notion of our intuitive ability to find (to even know) that we are on the right or correct path in life. Its voice bears the marks of the early years of marriage and motherhood, day-to-day struggles and a preoccupation with [re]constructing a hopeful vision of the future. "Wander Lines" listens and responds from a mature perspective drawn from experience of the instinctual forces that influence the decisions made at liminal moments in life. In its voice is heard the messiness of a life and career, and a preoccupation with developing an authentic, credible and congruent academic voice in middle-age. Around them the air vibrates with the sounds of "Lou's Modal Menagerie." Its co-created, noisy musical voice is inspired by the shared experiential joy of causing reverberations, replete with potential for self-revelation within the space between the reflected self and the imagined other.

\section{Movement 2-Arguments (Allegro con spirito) [Audio link]}

The sound of music dissipates, and a provocation lingers in the air. What of all this reflexivity, this concern with anxiety? Where does it lead? "On Becoming a Counsellor" starts to speak.

I entered therapy desperately wanting George to make me feel better... My illusionary world was broken, and I wanted him to fix it. George, however, refused to comply. I lunged into George's room with one objective. To make him understand my powerless fantasy and to have him come to my rescue. But, he stepped aside, and I fell to the floor (Kopp [1981] 1998). The pain of falling felt almost as great as the pain I was carrying, but it was nothing compared with the pain of the realisation that I had been living in an illusionary world of my own design. (Godwin 2006, 4) 
Adopting a researcher voice, "Wander Lines" interrupts with accusations of excessive reflexivity, claiming reflexivity has a role, but is not "a universal cure-all for the dilemmas of conducting research" (Day 2012, 82). It warns of the trap of using reflexivity as a "catharsis of self-awareness for the researcher" (Pillow 2003, 181), bluntly suggesting that while transparency might enhance understanding, transparency does not necessarily alleviate problems or offer solutions. The conversation concludes with "Wander Lines" commenting that excessive reflexivity risks creating identity instability and aggravate tendencies towards anxiety (Day 2012). But what is the alternative?, asks "On Becoming a Counsellor."

\section{Movement 3-The Call of the Mountains (Adagio-Andante-Adagio)} [Audio link]

After a period of silence, "Lou's Modal Menagerie" offers a reflection on the lived experience, quietly sharing thoughts on the intertwined relationship between joy and sorrow. It alludes to moments of sharing voice through music making of profound joy tempered by the sorrow associated with the knowledge that these moments can never be fully reclaimed or reproduced. It suggests that ego and desire for more of these moments threatens to diminish those experienced now through the realization that that they will not come again. Offering its own temporary conclusion, "Lou's Modal Menagerie" suggests that the existential source of sorrow is located in the joy these moments carry because they are small steppingstones toward accepting the inevitability that life itself is impermanent. Even while we are in these moments, we are consciously letting them go. There is but one option. To embrace risk and share our voice.

\section{Musings on the dialogic encounter}

We would rather be ruined than changed, We would rather die in our dread Than climb the cross of the moment And let our illusions die.

(Auden [1947] 2011, 105)

Writing about the process of writing confession, Lee (2007) speaks of the "transformative nature of intimate renderings" (6), describing the act of balancing "disclosure and secrecy" and the potential for "proclamations of change" (5). Reflecting on the present essay, I see moments of artifice and concealment, and moments of 
candor and attempts toward truthfulness. I recognize a structure that self-consciously aspires to be original and to create a space-as a doctoral candidate needing to build identity and voice as researcher-to improvise and play with selfdiscovery through writing. I hope it will open up possibilities within my evolving doctoral writing. This silent fourth actor in the dialogue reminds me of my attachment to the works of Hall (1991), Simon Frith (1996) and Antony Giddens (1991), and my framing of my understanding of identity through their writing. And they begin to speak.

Hall (1991) reminds me that there is no singular, authentic voice, for "[i]dentity is always in the process of formation" (47) and negotiated through "splitting between that which one is, and that which is the other...the Other that belongs inside one" (48). He points to my continuing attachment to old logics of identity founded on "a notion of the continuous, self-sufficient, developmental, unfolding, inner dialectic of selfhood" (42), which promises a "guarantee of authenticity" disclosed in the final revealing of "true self" (47).

From a sociological perspective, Giddens (1991) steps in to reassure and placate my desire to rewrite the present essay in fear of what might be revealed to the reader. For is this not what we all fear most in our writing? That we might expose to a reader something of ourselves-a belief, a prejudice, a weakness-we wish to conceal, or worse. That we might reveal something to ourselves that breaks our illusionary world. Is my attachment to anxiety an illusionary deceit: a light shone to disrupt the function of the one-way mirror I grasp? Giddens reminds me that my phenomenal world is a carefully curated blend of intentionally selected sources of direct and mediated information drawn from my experiences in the world, which may or may not comply with the dominant social norms, values and attitudes that continue to have traction in my life. He reassures me that the construction of identity involves dilemmas to reconcile, resolve or simply struggle with. He tells me to keep going.

Finally, Frith (1996) gestures toward "Lou's Modal Menagerie" to remind me that music offers an aesthetic experience through which I can experience myself differently. He argues, "first, that identity is mobile, a process not a thing, a becoming not a being; second, that our experience of music-of music making and music listening-is best understood as an experience of this self-in-process" (109). He asks me to listen more deeply to "Lou's Modal Menagerie" for, in his words, "music 
seems to be key to identity because it offers, so intensively, a sense of both self and other, of the subjective in the collective" (110).

And so, this essay, this dialogic conversation of three earlier works within the story of my essay, becomes a brief moment of "seeing-meaning" (van Manen 2007, 12) through which I reveal my continuous construction of self. It presents an example of the continual dialogue with "Other than belongs inside one" (Hall 1991, 48 ) that is the wellspring of my own identity project. This project is inextricably entwined with that part of myself which is associated with being a musician, the unfailing part of my identity that is my truth (Gouzouasis and Lee 2002; Lee 2004). Yet, it is not my only truth. Having promoted in this essay the binary notion of musician voice versus researcher voice, I now confess it as a constructed faultline that exists only in my imagination. My voice as musician or researcher, whether music, text or speech, is my sound. This sound is voice and identity as a socially- and individually-mediated process. And it is the place within my identity project where my intersecting images of self-self/other-meet in myself.

\section{Acknowledgements}

I extend my thanks to Peter Gouzouasis for guidance and encouragement, to the two peer reviewers for their generous and valuable feedback, and to my supervisor David Forrest for his comment and continuing support.

I acknowledge the people of the Woi wurrung and Boon wurrung language groups of the eastern Kulin Nations on whose unceded lands my research is conducted. I respectfully acknowledge their ancestors and Elders, past and present, and the Traditional Custodians and their Ancestors of the lands and waters across Australia.

\section{About the Author}

Louise Godwin is a cellist, arts manager and researcher. She received a Master in Education (Research) from RMIT University and a Bachelor of Music (Hons) from The University of Melbourne. Louise has taught cello in primary schools, held program coordination roles within institutions of higher music education, and worked in artist, project and concert management in community music and professional performing arts sectors. She is currently undertaking a PhD at RMIT University, Melbourne, exploring the diversification of artistic activities in music by professional classical musicians, with a particular focus on music making for social justice.

Godwin, Louise. 2019. The sound of my voice: Self-revelation through autoethnography. Action, Criticism, and Theory for Music Education 18 (2): 57-72. http://dx.doi.org/10.22176/act18.2.57 


\section{References}

Auden, William H. [1947] 2011. The age of anxiety: A baroque eclogue. Princeton, New Jersey: Princeton University Press.

Benjamin, Walter. 1969. Illuminations. New York: Schocken Books.

Bhabha, Homi. K. 1994. The location of culture. London, UK: Routledge.

Day, Suzanne. 2012. A reflexive lens: Exploring dilemmas of qualitative methodology through the concept of reflexivity. Qualitative Sociology Review 8 (1): $60-85$.

Deligny, Fernand. 2014. The arachnean and other texts. Translated by Drew S. Burk. Minneapolis: Univocal Publishing.

Ellis, Carolyn. 2004. The ethnographic I: A methodological novel about autoethnography. Walnut Creek, CA: Altamira Press.

Ellis, Carolyn, Tony E. Adams, and Arthur P Bochner. 2011. Autoethnography: An overview. Historical Social Research/Historische Sozialforschung 12 (1): 273-90.

Foot, Jessica, Louise Godwin, and Volga Tunca. 2017. Lou's Modal menagerie, recorded December 2017, track 3 on The Kitchen Project, compact disc.

Forster, Edward. [1910] 1997. Howards' end. London, UK: Macmillan.

Frith, Simon. 1996. Music and identity. In Questions of cultural identity, edited by P. du Gay and S. Hall, 108-127. London: Sage.

Giddens, Anthony. 1991. Modernity and self-identity: Self and society in the late modern age. Stanford, California: Stanford University Press.

Godwin, Louise. 2006. On becoming a counsellor (in the author's possession).

Godwin, Louise. 2017. Wander lines as visual metaphor for journeys in life and music (in the author's possession).

Gouzouasis, Peter. 2008. Toccata on assessment, validity, and interpretation. In Being with a/r/tography, edited by S. Springgay, R.L. Irwin, C. Leggo and P. Gouzouasis, 221-32. Rotterdam, The Netherlands: Sense Publishers.

Gouzouasis, Peter, and Karen Vickie Lee. 2002. Do you hear what I hear? Musicians composing the truth. Teacher Education Quarterly 29 (4): 125-41.

Godwin, Louise. 2019. The sound of my voice: Self-revelation through autoethnography. Action, Criticism, and Theory for Music Education 18 (2): 57-72. http://dx.doi.org/10.22176/act18.2.57 
Hall, Stuart. 1991. Old and new identities, old and new ethnicities. In Culture globalisation and the world system, edited by A.D. King. London: Macmillan.

Hilton, Leon. 2015. Mapping the wander lines: The quite revelations of Fernand Deligny. Los Angeles Review of Books, July 2. https://lareviewofbooks.org/ article/mapping-the-wander-lines-the-quiet-revelations-of-fernand-deligny/

Kierkegaard, Soren. [1844] 2014. The concept of anxiety: A simple psychologically oriented deliberation in view of the dogmatic problem of hereditary sin. Translated by Reidar Thomte. Princeton, New Jersey: Princeton University Press.

Kopp, Sheldon. [1981] 1998. If you meet the Buddha on the road, kill him!: The pilgrimage of psychotherapy patients. USA: Bantam Books Inc.

Lee, Karen Vickie. 2004. Riffs of change: Musicians becoming educators. Doctoral dissertation, University of British Columbia, Vancouver. https://open.library.ubc.ca/cIRcle/collections/ubctheses/831/items/1.0055047

Lee, Karen Vickie. 2007. Confessing takes courage. Forum Qualitative Sozialforschung/Forum: Qualitative Social Research 8 (1): n.p.

Milton, Damian. 2016. Tracing the influence of Fernand Deligny on autism studies. Disability and Society 31 (2): 285-9.

Morrison, Chris. n.d. Description. Charles Ives String Quartet No. 2 for string quartet, S. 58 (K. 2A3). Accessed 23 April 2018, https://www.allmusic.com/ composition/string-quartet-no-2-for-string-quartet-s-58-k-2a3mcooo2363701

Pillow, Wanda. 2003. Confession, catharsis, or cure? Rethinking the uses of reflexivity as methodological power in qualitative research. International Journal of Qualitative Studies in Education 16 (2): 175-96.

Richardson, Laurel, and Elizabeth Adams St Pierre. (2008). Writing: A method of inquiry. In Handbook of qualitative research, edited by N.K. Denzin and Y.S. Lincoln, Vol. 3, 959-78. Thousand Oaks, California: SAGE Publications.

van Manen, Max. 2007. Phenomenology of practice. Phenomenology and Practice $1(1): 11-30$.

Godwin, Louise. 2019. The sound of my voice: Self-revelation through autoethnography. Action, Criticism, and Theory for Music Education 18 (2): 57-72. http://dx.doi.org/10.22176/act18.2.57 


\section{Notes}

${ }^{1}$ Gouzouasis and Lee (2002) use the form of a fugue to structure the writing motives in this article. The authors consider that the device fails to achieve their original intentions due to an editorial decision to remove and change crucial sections. Gouzouasis (2008) uses a structural and harmonic analysis of the first movement of a Beethoven Piano Sonata (Op. 110) to guide and structure the writing. Again, an editorial decision not to include a complete analysis impedes the paper's comprehension to non-musician academics.

2 My 2006 essay attributes this quote to The Cambridge Companion to Kierkegaard however I have been unable to find the edition containing this quote.

3 The 'chop' is a bowing technique originating in bluegrass fiddle playing.

Godwin, Louise. 2019. The sound of my voice: Self-revelation through autoethnography. Action, Criticism, and Theory for Music Education 18 (2): 57-72. http://dx.doi.org/10.22176/act18.2.57 